\title{
Removal of COD and total nitrogen from palm oil mill effluent in flat- photobioreactor using immobilised microalgae Chlorella sp.
}

\author{
1, ${ }^{*}$ Elystia, S., ${ }^{2}$ Muria, R.S. and, ${ }^{1}$ Anggraini, L. \\ ${ }^{1}$ Department of Environmental Engineering, Faculty of Engineering, Riau University, Indonesia, 28293 \\ Panam, Pekanbaru, Indonesia. \\ ${ }^{2}$ Department of Chemical Engineering, Faculty of Engineering, Riau University, Indonesia, 28293 Panam, \\ Pekanbaru, Indonesia.
}

\author{
Article history: \\ Received: 11 July 2018 \\ Received in revised form: 16 \\ October 2018 \\ Accepted: 22 October 2018 \\ Available Online: 6 \\ November 2018 \\ Keywords: \\ Chlorella sp., \\ COD, \\ Immobilization, \\ Palm Oil Mill Effluent \\ (POME), \\ Total Nitrogen \\ DOI: \\ https://doi.org/10.26656/fr.2017.3(2).130
}

\begin{abstract}
Untreated palm oil mill effluent (POME) contains organic materials, tannin compounds and high in soluble solids that can damage the environment when discharged into inland waterways and cultivated lawns. Organic materials of the POME can be processed into an algae cultivation medium due to its mineral contents. In this study, Chlorella sp. was used to remove COD and total nitrogen in POME. Chlorella sp. has microscopic size, low specific gravity and, it is difficult to separate in wastewater. Chlorella sp. cells were trapped in the calcium alginate matrix to form a bead with a diameter of 3-4 mm. To obtain the highest removal efficiency of COD and the total nitrogen, different concentration of Na-alginate $(4 \%, 6 \%$, and $8 \%)$ were used to optimize the beads preparation at different contact times $(1,3,5$, and 7 days). Based on the results, the beads made from $8 \% \mathrm{Na}$-alginate concentration were able to eliminate, $11-62.46 \%$ total nitrogen efficiently, and 23-63.1\% COD efficiently on the seventh day. This showed that higher $\mathrm{Na}$ -alginate concentration has higher removal efficiency.
\end{abstract}

\section{Introduction}

Riau province is the largest area of palm oil in Indonesia, with a land area of 2.4 million hectares. The large plantation contributes to high production of palm oil mill effluent (POME) (Directorate General of Plantations, 2015). A ton of palm fruit bunches will produce 0.2 tons of Crude Palm Oil (CPO), 0.6 tons of palm liquid waste and remaining 0.2 tons are solid waste. This palm oil liquid wastewater contains organic carbon with a COD value more than $40 \mathrm{~g} / \mathrm{l}$, a nitrogen content about $0.2-0.5 \mathrm{~g} / 1$ as ammonia nitrogen and total nitrogen. When directly discharged into the environment without treatment, the high organic content of the POME will reduce the oxygen content in the river and damages to the ecosystem. Therefore, POME must be processed before disposal due to its high potential pollutants (Hadiyanto, 2013).

The high organic content in POME is nutritional for algae growth, especially in the photosynthesis reaction (Hadiyanto, 2013). Algae is a eukaryotic organism that is abundant in the environment because of their rapid proliferation. Wastewater treatment using algae produces biomass that can be used as a source of feed and energy.
The biomass comprises of lipids (60\%), protein (50$70 \%$ ) and carbohydrates (40\%) (Hadiyanto, 2013). In this study, algae Chlorella sp. was used to remove the organic matter in POME. The process was carried out inside the flat-photobioreactor. Chlorella sp. has high efficiency in photosynthesis (Zelith, 1971) and can absorb nutrients in the culture medium during its rapid growth (Qiao et al, 2009).

After completion of the wastewater treatment process, the biomass of Chlorella $\mathrm{sp}$.is reusable. However, because Chlorella sp. has microscopic size, low density and easily damaged it is difficult to separate Chlorella sp. from wastewater. Therefore, there is a need to immobilize Chlorella sp. The immobilization of Chlorella sp. was done using calcium alginate. Calcium alginate produces beads with a diameter of 3-4 $\mathrm{mm}$ containing the immobilized algae that enable the separation from the medium. In addition, the immobilization process will increase cell detention time in the wastewater (Lau and Tam, 1997).

This study is aimed to obtain the highest removal efficiency of COD and total nitrogen for POME treatment using immobilized microalgae Chlorella sp. 
The removal efficiency will be evaluated based on the concentration of $\mathrm{Na}$-alginate in the bead preparation and the contact time.

\section{Materials and methods}

\subsection{Wastewater sample}

Palm oil waste was collected from PTPN V Sei Pagar's fourth pond. A single grab sampling method was performed at the coordinate $\mathrm{N}$ : $00^{\circ} 19^{\prime} 42.00^{\prime}$ ' 'E: $101^{\circ} 21^{\prime} 07.8^{\prime \prime}$. The wastewater was filtered to eliminate large particles and sand that can damage the structure of alga beads. The filtered wastewater was tested to determine the initial content of COD and total nitrogen.

\subsection{Alga stock culture}

Chlorella $s p$. was cultivated in the Dahril solution medium for ten days at the Algae Research Center of the Faculty of Fisheries, Riau University. Sunlight was used as a natural light source. During cultivation, the cell numbers were counted under the microscope with thoma cell counting chamber every $24 \mathrm{hrs}$.

\subsection{Alga beads immobilisation}

The immobilization process in this study was based on the method by Singh et al. (2012). Chlorella sp. were incubated for 10 days and then separated from the medium by centrifugation at $4000 \mathrm{x} g$ force for 10 mins. Algae cell residues were washed with aquadest three times and suspended in aquadest to form an algae suspension with a density of $1 \times 10^{14}$ cells $\mathrm{ml}^{-1}$. The algae suspension was homogenized by stirring to cell clumps. The homogenized suspension of algal cells was mixed with sodium alginate solution at various concentrations of $4 \%, 6 \%, 8 \%(\mathrm{w} / \mathrm{v})$. The comparison of algae and Na-alginate $1: 1$ volume, so that the concentration of algae-alginate mixture formed was $2 \%$, $3 \%$, 4\%, respectively. The algae-alginate solution mixture was dropped into a $0.5 \mathrm{M} \mathrm{CaCl}_{2}$ solution using a peristaltic pump to form uniform algae beads. Algae beads were left in a solution of $\mathrm{CaCl}_{2}$ for $12 \mathrm{hrs}$ at $4^{\circ} \mathrm{C}$ for proper hardening. The formed algae beads were washed with $0.8 \% \quad \mathrm{NaCl}$ sterile solution and subsequently with distilled water.

As controls, blank beads containing no algae cells and free cells algae were prepared. The blank beads were prepared similarly, except distilled water was used instead of algal cell suspension. Both free algae beads and immobilised algae beads were fed into the wastewater medium at the same concentration.

\subsection{Design of flat-photobioreactor}

The flat-photobioreactor design in this study consisted of five boxes made of flat glass with dimensions of $30 \times 10 \times 20 \mathrm{~cm}$ with a $3 \mathrm{~L}$ capacity. The first and second flat-photobioreactor act as controls. The first flat-photobioreactor were filled with free algae cells and the second flat-photobioreactor were filled with blank beads. The other three were filled with immobilised algae beads. All five flat-photobioreactors were placed in a light chamber measuring $1.5 \times 0.5 \times 0.6$ $\mathrm{m}$. The white-cool fluorescent lamp with a light intensity of $5000 \pm 300$ lux was used as the light source (Choochote et al., 2010). The interior of the light chamber was wrapped with aluminium foil so that the resulting light intensity can be quantized so that the photobioreactor gets maximum light exposure (Daniyati et al., 2012) (Figure 1).

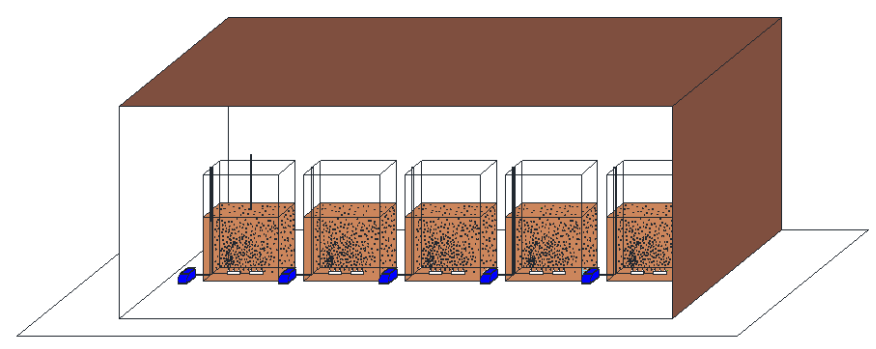

Figure 1. Flat-Photobioreactor

Three tubes were fixed on the top of flatphotobioreactor with the following purpose; the first tube served as an inlet channel for the wastewater from the influent tube into the photobioreactor; the second tube is to provide aeration to increase contact between algae and wastewater at a flowrate of $3 \mathrm{~L} / \mathrm{min}$; and the third tube is used to extract treated wastewater from the flatphotobioreactor. The reactors were also equipped with an influent container of 20 liter capacity and an effluent container of $500 \mathrm{~mL}$ capacity.

\subsection{Flat-photobioreactor operation}

The flat-photobioreactor was designed for treatment of POME. A total of three flat-photobioreactors were filled with immobilised algae beads at the concentration of 10 beads $\mathrm{ml}^{-1}$, while the other two photobioreactors contained blank alginate beads and free algae cells as controls at the same concentration as immobilised algae beads. Then, $3 \mathrm{~L}$ of POME was fed into each flatphotobioreactor. All flat-photobioreactors were aerated continuously using aeration pump at a flow rate $3 \mathrm{~L} / \mathrm{min}$. The flat-photobioreactors were operated at room temperatures under the light intensity of $5000 \pm 300$ lux from a cool-white fluorescence LED lamp for $12 \mathrm{hrs}$ in a cycle. One cycle of illumination consisted of $12 \mathrm{hrs}$ of light and 12 hrs of dark.

The POME treatment in the flat-photobioreactors was conducted for seven days consecutively. On the first, third, fifth, and seventh day, treated wastewater was 
collected and analysed for the COD content and total nitrogen.

In addition, the cell density in the algae beads was counted daily during the process. A total of ten algae beads were taken out from each flat-photobioreactor and dissolved in $1 \mathrm{~mL}$ of sterile sodium citrate $0.2 \mathrm{M}$ for 30 mins at room temperature to dissolve the algae beads. The dissolved algae beads were diluted with aquadest and the algae cells were counted using at hemacytometer under a light microscope. The growth of algae cells within beads has calculated using the equation below:

$$
\text { Growthrate }(\mu)=\frac{\left(\log _{10} \mathrm{x}_{2}-\log _{10} \mathrm{x}_{1}\right)}{\Delta \mathrm{t}}
$$

\section{Results and discussion}

\subsection{Growth of immobilised Chlorella sp.}

The number of cells of Chlorella sp. in each bead in all the flat-photobioreactor was $1 \times 10^{7}$ cells $/ \mathrm{mL}$. Figure 2 shows an increase in the number of algae cells in the during the treatment of POME in all the flatphotobioreactor. The increase in cell numbers indicated that Chlorella sp. after immobilization were able to survive and perform cell division inside the beads alginate. A previous study had shown that immobilised Chlorella minutissima cells with alginate were able to maintain the continuity and activation of catalysts cells (Singh et al., 2012).

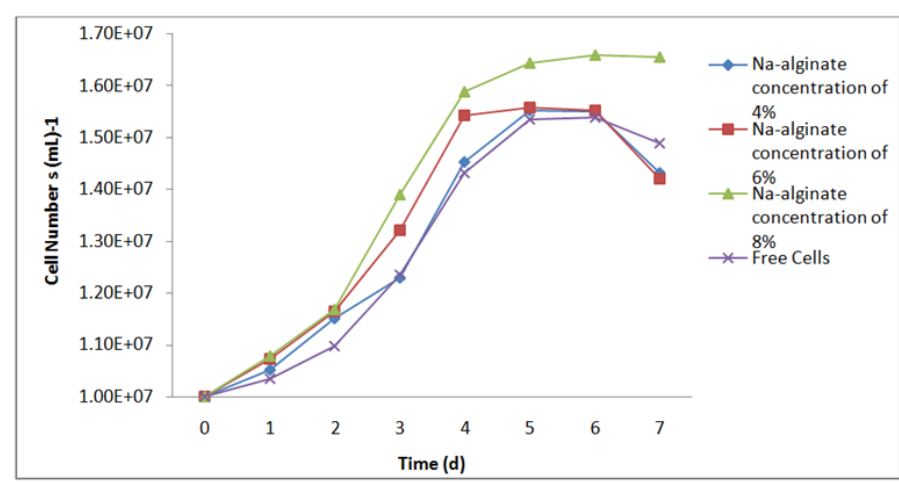

Figure 2. Algae cell density in different concentrations of Na-alginate throughout the POME treatment

According to Figure 2, 8\% Na-alginate immobilised algae beads had the highest cell density while $4 \% \mathrm{Na}$ alginate immobilised algae beads had the lowest cell density. This showed that the best algal cell growth occurred within immobilised algae beads with an $8 \% \mathrm{Na}$ alginate concentration. Immobilised algae cells had a larger number of cells than the free algae cells. This is due to the free algae cells are indirect contact with the wastewater, exposing the cells to physical and chemical pressures which resulted in longer adaptation processes (Singh et al., 2012).

Chlorella sp. trapped inside of the beads have a smaller size than the pores of the bead. The wastewater solution can enter the beads through the pores. The cells absorb the organic matter in wastewater as a source of nutrients for cell growth and metabolism (de-Bashan and Bashan, 2010). The immobilised cell has a longer retention time. As a result, the cells become better adapted to the wastewater substrate and the risk of the cell carrying in the waste medium can be reduced, no cell separation is required, and cell metabolic activity remains constant for a long time (Lukavski et al., 1986).

\subsection{Efficiency removal of total nitrogen in POME}

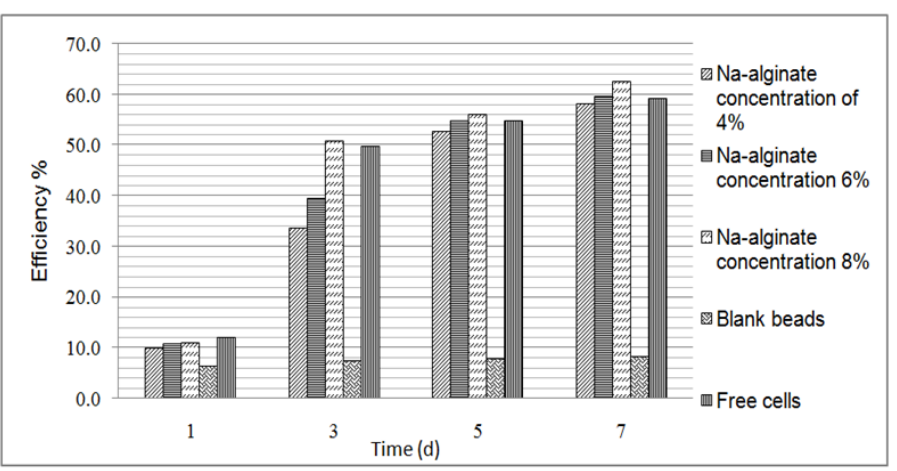

Figure 3. Efficiency removal of total nitrogen

The efficiency of the total nitrogen removal in the wastewater can be seen in Figure 3. Figure 3 shows that the most efficient total nitrogen removal occurs in the flat-photobioreactors contained immobilised Chlorella sp. made of $8 \%$ alginate concentration. occurring on the seventh day with $62.46 \%$ removal efficiency. In $4 \% \mathrm{Na}-$ alginate immobilized algae beads, the highest total nitrogen removal efficiency occurred on the seventh day of $58.2 \%$ removal. The algae beads made with a concentration of $6 \%$ Na-alginate had the removal efficiency of $59.5 \%$ on the seventh day. The free algae cells had a total nitrogen removal efficiency of $59.2 \%$ occurred on the seventh day. The total nitrogen removal efficiency in flat-photobioreactor contained blank beads at the end of treatment only reached $8.3 \%$. The decrease in total nitrogen concentration in flat-photobioreactor contained the empty bead control occurs due to the absorption and binding of nitrogen by the carboxyl group present in the calcium alginate matrix (Lau et al., 1997).

Based on Figure 3, it is shown that the nitrogen removal pattern increases with the treatment time. A longer treatment time allows a longer contact time of Chlorella sp. with wastewater and thus, increasing the number of cells to efficiently remove the total nitrogen

The highest nitrogen efficiency occurs in beads with $8 \%$ concentration because it has the highest number of cells compared to the immobilised algae beads at $4 \%$ and $6 \%$ Na-alginate concentration. Low cell concentrations decrease the efficiency of organic material removal (Zhang et al., 2008). 
Similarly, a research conducted by Wang et al. (2016) showed that the highest rate of removal occurs in algae with the highest cell density causing assimilation of nutrients and carbon dioxide, which causes an increase in $\mathrm{pH}$ value in the medium. Other studies have also shown that high $\mathrm{pH}$ can lead to the evaporation of ammonium which leads to increased efficiency of nutrient removal (Tam and Wong, 2000).

\subsection{Efficiency removal of COD in the palm oil mill effluent}

The concentration of COD in the wastewater during treatment in the flat-photobioreactor using Chlorella sp. cells with the variation of sodium alginate concentration and treatment time shown in Figure 4.

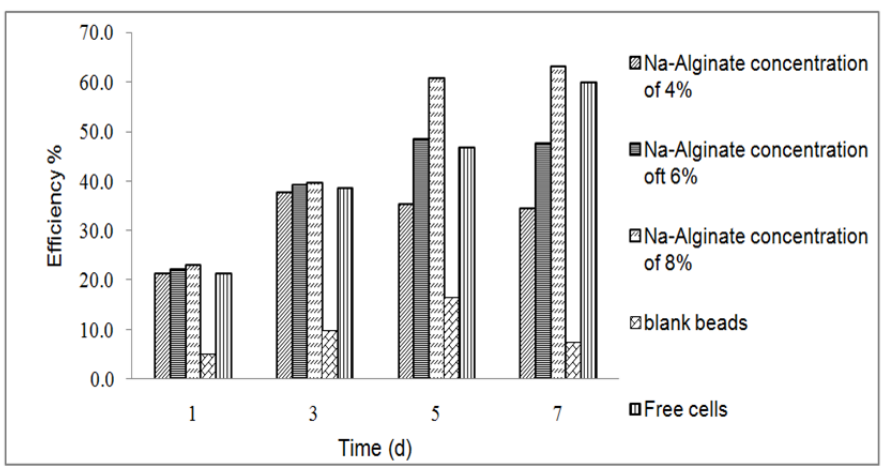

Figure 4. Efficiency removal of COD

At the end of the treatment day, the highest COD removal occurred immobilised algae beads made from $8 \%$ Na-alginate of $63.1 \%$ COD removal. In the algae without immobilised algae beads, the COD removal was $59.8 \%$. Immobilised algae beads made from $4 \% \mathrm{Na}$ alginate on the third day had a removal efficiency of $37.7 \%$. However, on the fifth and seventh day, there was a decrease in the COD removal whereby only $35.2 \%$ and $34.4 \%$ were removed respectively. The maximum COD removal with immobilised algae beads made from $6 \%$ Na-alginate occurred on the fifth day with $48.4 \%$ of COD removal. On the seventh day, there was a decrease whereby $47.5 \%$ of COD was removed. The decreased efficiency was due to the dissolution of the alginate matrix, causing leakage of cells that become carbon contributor to wastewater.

The process of assimilating organic carbon in the waste medium by Chlorella sp. occurred during cellular respiration. The organic compound was used as an electron donor while oxygen consumed as the final electron acceptor. This respiration has two main functions: exclusive energy provider for treatment and biosynthesis in dark conditions. In this mixotrophic growth, the cells will use inorganic carbon sources $\left(\mathrm{CO}_{2}\right)$ and organic carbon derived from the waste medium alternately (Perez-Garcia and Bashan, 2010).
The blank beads flat-photobioreactor removed $4.9 \%$, $9.8 \%, 16.4 \%$ and $7.4 \%$ on the first, third, fifth and seventh day of treatment respectively. The low efficiency of removal of COD in the blank beads flatphotobioreactor was due to the presence of a carboxyl functional group which binds to the organic material only (Singh et al., 2012). In addition, organic material in wastewater can be reduced due to decomposition of the present natural bacteria.

\section{Conclusion}

The highest efficiency of COD removal and total nitrogen occurred in flat-photobioreactors contained immobilised algae beads made of $8 \%$ Na-alginate whereby $63.1 \%$ and $62.5 \%$ of COD and total nitrogen was removed efficiently on the seventh day of contact. The concentration of $8 \%$ Na-alginate was able to protect the immobilised algae, allowing the algae to continuously grow. With a longer contact time and high cells density, it can be assumed that COD and total nitrogen can be removed more efficiently from POME.

\section{References}

Choochote, W., Paiboonsin, K., Ruangpan, S. and Phauruang, A. (2010). Effects of urea and light Intensity on the growth of Chlorella sp. The 8th International Symposium on Biocontrol and Biotechnology. Retrieved from website: https:// pdfs.semanticscholar.org/ ce4f/6a67588512d5d3dfa305f76e7a6f97cfbba5.pdf

Daniyati, R., Yudoyono, G. and Rubiyanto, A. (2012). Design of closed photobioreactor in Chlorella vulgaris for mitigation of $\mathrm{CO}_{2}$ emissions. Journal Science and Art, 1, 1-5

De-Bashan, L.E. and Bashan, Y. (2010). Immobilised microalgae for removing pollutants: Revise of Practical Aspects. Bioresource Technology, 101(6), 1611-1627. https://doi.org/10.1016/ j.biortech.2009.09.043

Directorate General of Plantations. (2015). Indonesian Plantation Statistics Oil Palm Plantation. Jakarta: Directorate General of Plantations.

Hadiyanto. (2013). Valorization of Microalgae for Palm Oil Liquid Waste Processing and as a Source of Alternative Energy and Food. Proceedings of Chemical and Process Engineering, 1-11

Lau, P.S., Tam, N.F.Y. and Wong, Y.S. (1997). Wastewater nutrient ( $\mathrm{N}$ and $\mathrm{P}$ ) removal by carrageenan and alginate immobilised Chlorella vulgaris. Environment Technology, 18(9), 945-951. https://doi.org/10.1080/09593331808616614

Lukavski, J., Komarek, J., Lukavska, A. and Ludvik, J. 
(1986). Metabolic activity and cell structure of immobilised algal cells. Archiv fur Hydrobiologie, Supplement, 73(2), 261-279.

Perez-Garcia, O., de-Bashan, L.E.J., Hernandez, J-P. and Bashan, Y. (2010). Efficiency of growth and nutrient uptake from wastewater by heterotrophic, autotrophic and mixotrophic cultivation of Chlorella vulgaris immobilized with Azospirillum brasilense. Journal of Phycology, 46(4), 800-812. https:// doi.org/10.1111/j.1529-8817.2010.00862.x

Qiao, H., Wang, G. and Zhang, X. (2009). Isolation and characterization of Chlorella sorokiniana GXNN01 (Chlorophyta) with the properties of heterotrophic and microaerobic growth. Journal of Phycology, 45 (5), 1153-1162. https://doi.org/10.1111/j.15298817.2009.00736.x

Singh, S.K., Bansal, A., Jha, M.K. and Dey, A. (2012). An integrated approach to remove $\mathrm{Cr}(\mathrm{VI})$ using immobilised Chlorella minutissima grown in nutrient rich sewage wastewater. Journal of Bioresource Technology, 104, 257-265. https://doi.org/10.1016/ j.biortech.2011.11.044

Tam, N.F.Y. dan Wong, Y.S. (2000). Effect of immobilised microalgal bead concentration on wastewater nutrient removal. Environmental Pollution, 107(1), 145-151. https://doi.org/10.1016/ S0269-7491(99)00118-9

Zelith, I. (1971). Photosynthesis, photorespiration and plan productivity. New York: Academic Press.

Zhang, E., Wang, B., Wang, Q., Zhang, S. and Zhao, B. (2008). Ammonia-nitrogen and orthophosphate removal by immobilised Scenedesmus sp. isolated from municipal wastewater for potential use in tertiary treatment. Bioresource Technology, 99(9), 3787-3793. https://oi.org/10.1016/ j.biortech.2007.07.011 